\title{
PESTICIDES BIOACCUMULATION AND THEIR SOIL POLLUTANT
} \section{EFFECT}

*B. A. Othman

Researcher
E. S. Kakey

Prof.

Dept. Biol. Faculty of Science and Health, Koya University Koya KOY45, Kurdistan Region F.R. Iraq.

\section{ABSTRACT}

bakhtyar.abdullah@koyauniversity.org*, email.kakey@koyauniversity.org

This study was aimed to investigate pesticides bioaccumulation and their soil pollutant effect. The experiment was included sixteen active greenhouses in Erbil plane, and conducted during September 2017 and March 2018. The present study revealed that the pesticides residue of pyridabine, thiamethoxam, abamectin and spirodiclofen were detected in greenhouse soil samples. The values of soil heavy metals contaminations factor $(C F)$ revealed, that the studied greenhouse soil samples were ranged from low to very high contamination, while for pesticides were ranged from non to high contaminated. Soil pollution load index results supported that, the greenhouse soil was contaminated especially by $\mathrm{Cr}$, $\mathrm{Ni}$ and Co. Pollution load index (PLI) was ranged from 7.751 to 0.303; supporting that the soils were contaminated in most sites. It could be concluded that, significant need for the development of pollution prevention and scientific strategies to reduce heavy metal pollution and pesticide accumulation residuals within greenhouses in Erbil plane.

Keywords: greenhouse, pesticide residue, heavy metal contamination, soil pollution.

عثمان و كاكيي

47-36:1) 5جلة العلوم الزراعية العراقية - 2021 :

$$
\text { التراكم الأحيائي للمبيدات ومؤشرات تأثيراتيها الملوثة للتربة }
$$

$$
\text { إسماعيل صالح ابراهيم كاكيي }
$$$$
\text { بختيار عبدا لله عثمان }
$$

المستخلص

تهدف التجربة لاراسة التراكم الاحيائي للمبيدات ومؤثشرات تأثيراتها الملوثة للتربة. اشتملت الاراسة على ستة عشر بيتا

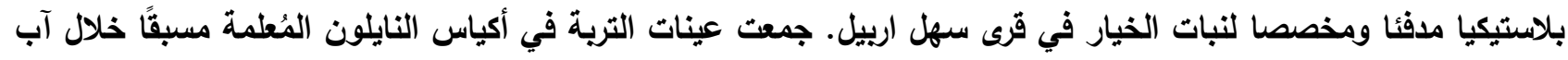

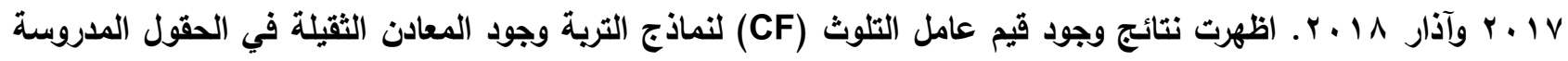
بنسب مختلفة تتراوح بين التلوث المنخفض والتلوث العالي للغاية. في حين أظهرت قيم عامل تلوث التربة بوجود تدريجي في نسب التلوث من حالة عدم وجود تلوث الى حالات تلوث عالي في نماذج التربة، من ناحية أخرى، أظهرت نتائج مؤثر حمولة

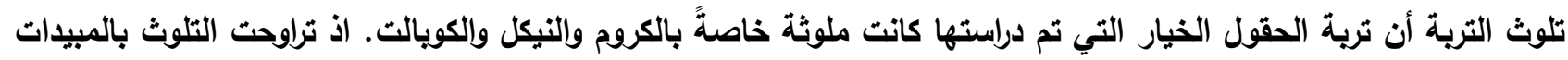
المتراكمة في عينات التربة (7.751 إلى 0.303) خلال فترة الدراسة وان هذه النتائج توكد تلوث التربة في حقول الخيار خلال

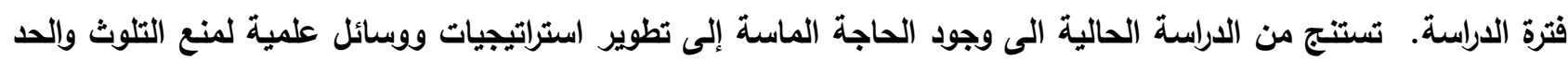
من التلوث بالمعادن الثقيلة ويقايا تراكم المبيدات المستخدمة في الحقول في مناطق سهل التهل اربيل. الكلمات المفتاحية: حقول الدفيئة، مخلفات مبيدات، تلوث بالمعادن الثقيلة، تلوث التربة. 


\section{INTRODUCTION}

Urban communities and industries continuously charge the environment with xenobiotic organic chemicals, many thousands of organic trace pollutants were produced during the last decades and partially released into the environment (40). Plant production yield is exposed to harmful organisms on a going basis. Protecting plants and plant products from such organisms, preventing yield or damage, and ensuring high quality of harvested products and high agricultural productivity are essential (37). Pesticides were frequently used to enhance productivity and control pests, so the consumption of food is among the main routes of consumer exposure to pesticides (21). Due to their huge potential toxicity, high persistence and slow degradation, environmental pollution with pesticides are within of the most important problems facing the nation. Evaluating the health and environmental impacts of pesticides seems to be challenging because of multi stressors and habitat complexity, so markers have been extensively used to connect external levels of pollutant exposure, internal levels of tissue contamination, and early negative effects in life forms. Hence the use of markers could be an important line of evidence for comprehending the relations between stressors and effects on adjacent resources and for preventing detrimental effects of contamination on the community (20). Greenhouse cucumber plantations are actually considered to be a large - scale vegetable crop grown in Erbil City, but many insects attack the plant and then frequently used insecticides. Most greenhouse plants use abamectin, thiamethoxam, pyridabin, and spirodiclofen to control the various insects. Excessive and unnecessary use of pesticides has numerous adverse impacts on the environment and overall health of people who are exposed to pesticides actively or passively. The main of Erbil's problems in greenhouses is the paucity of an assessment based on empirical data on local farms, landowners in Erbil are typically not well informed about chemical selection and application techniques. There is even a lack of willingness in some cases and in some places to apply the necessary dosage. This study was aimed to evaluation of the residual pesticides as well as, heavy metals through using contamination factor and the pollution load index. Which help adopt an effective effluent management strategy towards control over enhanced metal levels with recycling of effluents for toxic metal separation and soil remediation and reclamation.

\section{MATERIALS AND METHODS}

Soils samples at sixteen active greenhouse fields in pre-labelled nylon bags were collected during September 2017 and March 2018. Studied sites located within villages: Jmka, Dhemat, Meer, Grdazaban, Perdawd, Sherawa, Quchablbas, Qarachnagha, Murtka, and Sablakh. The soil samples were collected from the upper layer of the soils $(0-30 \mathrm{~cm}$ depth) at a random pattern around each field, according to USAID, (39). The soil samples were brought to the biology laboratory. A compost was formed for each field subsamples, dried, and stored for analyzing. A portion from each sub-sample was sent to the physics laboratory for further analyses with Xray fluorescence spectrometry.

\section{Extraction of soil samples}

Soil samples $(0.1 \mathrm{~g})$ was placed in a $2 \mathrm{ml}$ Eppendorf tube, $200 \mu 1$ of water was added to the sample, rigorously mixed with the VortexGenie 2 and left on the Hula - Mixer for one hour with a reciprocal degree of $90^{\circ} \mathrm{C}$, after adding $300 \mu \mathrm{l}$ acetonitrile, the samples were mixed again with the Vortex-Genie. The sample was centrifuged at $12000 \mathrm{rpm}$ for 10 minutes, and then the solvent phase was collected and diluted 4.8:1 in a $200 \mu \mathrm{l}$ vial with water ( $150 \mu \mathrm{l}$ solvent phase, $31 \mu 1$ water).

\section{HPLC Instrumentation}

Through using Agilent 1260, Infinity HPLC system w/1290 infinity thermostat, pyridabin, abamectin, thiamethoxam, and spirodiclofen insecticides were determined in extracted soil samples. Stainless steel column C18 (300 mm long, $4.6 \mathrm{~mm}$ ) packed with octadecylsilyl silica gel for chromatography $(5 \mu \mathrm{m}$ particle size) at column temperature $30^{\circ} \mathrm{C}$ was used. Acetonitrile - water was selected using a UV wavelength of $254 \mathrm{~nm}$ as a mobile phase at a flow rate of $1.0 \mathrm{ml} / \mathrm{min}$. Retention time (Rt) for Pyridabin, Abamectin, thiamethoxam, and Spirodiclofen pesticide detection were 2,455 , $8,187,11,893$, and 42,793 minutes respectively, after compression with known 
standard under the same conditions. On the basis of the peak area, the quantities were calculated. $20 \mu \mathrm{l}$ injection volumes were used in all experiments, and LC solution software controlled the chromatographic device.

\section{Soil heavy metal analysis}

$\mathrm{X}$-ray fluorescence spectrometry (XRF) was used for soil analyses. This technique is the rapid qualitative and quantitative determination of major, minor, and trace elements in a wide variety of soil samples, which does not require extensive training or experience on the part of the analysis. The samples were placed in the chamber and measured by a $20 \mathrm{~mm}$ diaphragm in a vacuum. The spectrometer is the main unit that consists of the sample chamber and the block unit. After pressing soil samples to palettes, chemical compositions of the soil samples were then measured and analysed data will be shown on programmed computer monitor after changing detected target points and converting to true numbers (27).

\section{Soil contamination factor $(\mathrm{CF})$}

The ratio of soil contamination factor was obtained by dividing the concentration of a specific soil heavy metal or pesticides in the soil samples by the background value of that parameter. Which can be calculated by $(\mathrm{CF}=$ $\mathrm{C}_{\mathrm{m}} / \mathrm{C}_{\mathrm{b}}$ ). where $\mathrm{C}_{\mathrm{m}}$ is the heavy metal or pesticide concentration in a soil sample, and $\mathrm{C}_{\mathrm{b}}$ is the background value of the heavy metal or pesticide (18).

\section{Soil pollution load index (PLI)}

The PLI was obtained as a concentration factor of each soil variable with respect to the background value in the soil. The PLI is able to give an estimate of the metal or pesticide contamination status and the necessary action that should be taken. Where a value of PLI $<1$ denotes perfection; PLI $=1$ denotes that only baseline levels of pollutants are present and PLI > 1 would indicate deterioration of site quality. The PLI for a single site is the $n$th root of $n$ number multiplying the contamination factors (CF values) together $(\mathrm{PLI}=\mathrm{n} \sqrt{ }(\mathrm{CF} 1$ $\left.{ }^{*} \mathrm{CF} 2 * \mathrm{CF}^{*}{ }^{*} \ldots \mathrm{CFn}\right)$. Where $\mathrm{CF}=$ contamination factor, $n=$ number of metals (34).

\section{RESULTS AND DISCUSSION}

The analysis of pesticide revealed that, the higher concentration of abamectin residue in greenhouse cucumber soil samples was 0.0591 ppm to non-detected with means of $0.01 \pm 0.005 \mathrm{ppm}$ (Table 1). The current study revealed that abamectin residues was detected in selected greenhouses with level more than the permissible MRL of this pesticide. For instance, soil samples in sites 1, 7, 11 and 16 were contaminated with abamectin residue more than MRL. Recently the abamectin residue was detected by Khan et al (18) in greenhouse soil fields upper than its concentration in open fields. Because abamectin is nearly insoluble in water and has a strong tendency to bind to soil particles, therefore it is regarded as immobile in soil (16). Previous studies reported that, abamectin's degradation is rapid and its physico-chemical properties prevent its bioconcentrating or bioaccumulating in the environment $(14,15)$. The results of soil thiamethoxam pesticide residues showed the higher concentration $1.737 \mathrm{ppm}$ in site 14 to non-detected as the lower concentration, with mean of $0.273 \pm 0.14$ (Table 1). Current investigation showed that, thiamethoxam residues in selected greenhouses were detected in most studied samples and its concentration were more than the permissible MRL of these pesticide except in some sites that might been due to application properties, humidity, temperature and soil $\mathrm{pH}$ of the studied greenhouses. Environmental thiamethoxam concentrations were positively correlated with greenhouse old and use in cultivated crop, the highest concentration of soil thiamethoxam were recorded in old greenhouse that's due to long half-life and slow degradation, as observed by (42). The highest concentration of spirodiclofen was ranged from 0.93 to nondetected as a lower concentration, with mean $0.335 \pm 0.099$ (Table 1) in soil samples. The results of the current study revealed that, the detected spirodiclofen residues in most studied greenhouses soil samples were more than the permissible MRL. The hydrolytic stability of spirodiclofen decreases as temperature and $\mathrm{pH}$ increase, in which the half-life for spirodiclofen at $20^{\circ} \mathrm{C}$ was calculated as 52.1 days at natural $\mathrm{pH}$. Spirodiclofen is rapidly degraded in soils and has a low mobility due to high soil sorption. In areas with high risk of erosion and run-off, transport of spirodiclofen 
sorbed to soil particles is likely to occur (36). The physical and chemical properties of spirodiclofen are characterized by its low water solubility, hydrophobicity, and tendency to bind to soil (7). The highest concentration of pyridabin pesticide residue was $10.96 \mathrm{ppm}$ and non-detected as lower concentration in greenhouse soil samples respectively. The overall mean was $0.204 \pm 0.089$ (Table 1). These results revealed that, recorded pyridaben residues in most studied greenhouses were more than the permissible MRL of these pesticides, however, in some studied samples pyridaben were not detected. These results were in agreement with some previous studies
$(24,26)$. Previously reported that, pyridaben is within non-leacher pesticide class, pyridaben was strongly adsorbed within top $20 \mathrm{~cm}$ soil layer, non-detection has been observed from 20-60 cm soil depth (13). Pyridaben was stable to hydrolysis but has a short photolysis halflife in soil. Furthermore, pyridaben has a short half-life in soil (12 to $14 \mathrm{~d}$ ) when applied in the field. As well as, physical and chemical factors, such as light, heat, $\mathrm{pH}$, and moisture play significant roles in pesticide bioconcentration in soil (35), and has high volatility that predicted to volatilize from moist soil (4).

Table 1.Detected soil pesticide residuals during studied period

\begin{tabular}{|lllll|}
\hline Sites & abamectin & Thiamethoxam & Spirodiclofen & Pyridaben \\
\hline Site1 & $\mathbf{0 . 0 3 4 7 2}$ & $\mathbf{0 . 1 0 6 0 6}$ & $\mathbf{0 . 9 2 1}$ & $\mathbf{0 . 3 9 7 5}$ \\
Site2 & ND & $\mathbf{0 . 0 1 0 8 2}$ & ND & $\mathbf{0 . 0 0 3 3}$ \\
Site3 & ND & $\mathbf{0 . 0 1 1 1 3}$ & ND & ND \\
Site4 & ND & $\mathbf{0 . 0 0 9 2 2}$ & ND & $\mathbf{0 . 0 5 0 5 2}$ \\
Site5 & ND & ND & ND & $\mathbf{0 . 0 5 1 9 4}$ \\
Site6 & ND & $\mathbf{0 . 0 0 6 6 8}$ & ND & ND \\
Site7 & $\mathbf{0 . 0 5 6 8 3}$ & $\mathbf{0 . 1 0 4 7 6}$ & $\mathbf{0 . 9 0 1 4 8}$ & $\mathbf{0 . 0 6 2 1}$ \\
Site8 & ND & $\mathbf{0 . 0 0 5 0 4}$ & $\mathbf{0 . 0 2 7 2}$ & ND \\
Site9 & ND & $\mathbf{0 . 0 1 3 8 6}$ & $\mathbf{0 . 0 3 9 8 6}$ & $\mathbf{0 . 0 4 2 7 6}$ \\
Site10 & ND & ND & $\mathbf{0 . 0 3 9 5}$ & $\mathbf{0 . 0 6 3 6 2}$ \\
Site11 & $\mathbf{0 . 0 5 9 1 3}$ & $\mathbf{0 . 1 0 5 1 5}$ & $\mathbf{0 . 8 9 4 2}$ & $\mathbf{0 . 0 6 1 3 8}$ \\
Site12 & ND & $\mathbf{0 . 1 0 6 4 3}$ & $\mathbf{0 . 9 3}$ & $\mathbf{0 . 0 6 4 1 9}$ \\
Site13 & ND & $\mathbf{0 . 1 3 8 7}$ & $\mathbf{0 . 0 6 6 9 4}$ & $\mathbf{0 . 0 8 9 1 3}$ \\
Site14 & ND & $\mathbf{1 . 7 3 6 8}$ & $\mathbf{0 . 6 0 6 8 6}$ & $\mathbf{1 . 0 9 6}$ \\
Site15 & ND & $\mathbf{1 . 7 3 6 5}$ & $\mathbf{0 . 5 9 5 4 6}$ & $\mathbf{1 . 0 8 0 5}$ \\
Site16 & $\mathbf{0 . 0 1 0 0 5}$ & $\mathbf{0 . 2 7 2 7 4}$ & $\mathbf{0 . 3 3 4 8 3}$ & $\mathbf{0 . 2 0 4 2}$ \\
Mean & $\mathbf{0 . 0 1 0}$ & $\mathbf{0 . 2 7 3}$ & $\mathbf{0 . 3 3 5}$ & $\mathbf{0 . 2 0 4}$ \\
SD & $\mathbf{0 . 0 2 0 6 8}$ & $\mathbf{0 . 5 7 6 2}$ & $\mathbf{0 . 3 9 7 9}$ & $\mathbf{0 . 3 5 8 9}$ \\
SE & $\mathbf{0 . 0 0 5 1 7 1}$ & $\mathbf{0 . 1 4 4 1}$ & $\mathbf{0 . 0 9 9 4 8}$ & $\mathbf{0 . 0 8 9 7 2}$ \\
\hline
\end{tabular}

Soil samples revealed that, recorded heavy metals levels exceeded the limited value that accepted by WHO (43), that might be due to intrusion of pollutants through industries, such as oil refineries, electroplating and mining activities, as well as, agricultural activities as application of pesticides, fertilizers and livestock manure $(5,17,23)$. Arsenic present in studied soil samples, the value was $(10.98 \pm 0.49$ and $11.33 \pm 0.48)$ ranged from (6 $\mathrm{mg} / \mathrm{kg}$ ) in site 6 during March and September as a minimum value to $(14.7 \mathrm{mg} / \mathrm{kg})$ in site 16 during September as a maximum value) during the studied period. Statistically, there were significant differences at $(\mathrm{P}<0.01)$ among studied samples during studied period (Figure 1). The fluctuation between studied sampling dates could be due to excessive application of pesticides, fertilizer, discharge wastes of factories and refinery projects, also domestic solid waste dumping and Erbil main sewer system. Lately study reported that soil As concentrations show significant enhancement, especially during growing season because of increasing application of pesticides and chemical fertilizers (33). Previous study stated that concentration of arsenic in greenhouse soil raises during irrigation with arsenic-rich water; also, during the dry season, As level was higher than the wet season (11). Studied soil sample recorded $(59 \pm 1.8$ to $69.5 \pm 2.4 \mathrm{mg} / \mathrm{kg})$ as $\mathrm{Cu}$ concentration variation from first to second sampling date, and statistically, there were significant differences at $(\mathrm{P}<0.05)$ among studied samples (Figure 2). The total $\mathrm{Cu}$ concentration was ranged from (48 to 91 $\mathrm{mg} / \mathrm{kg}$ ). The highest value was recorded during September in site 10 and the lowest value during March in site 8 during date of sampling. Cupper was significantly 
accumulated in greenhouse soil, which increased with the increasing of cultivation time, increasing organic matter and application of pesticides (10). Advanced research reported that $\mathrm{Cu}$ level in high concentration, could be result from different fertilizer and pesticide applications (25). Foregoing study suggested that, the level of $\mathrm{Cu}$ was mainly controlled by the anthropogenic sources as pesticide and fertilizer applications that contain a high amount of heavy metals (38). The mean concentration of total Co was $(124 \pm 3.66$ and $129.7 \pm 3.4 \mathrm{mg} / \mathrm{kg})$, that recorded $(10.0 \mathrm{mg} / \mathrm{kg})$ in site 6 during March as a minimum value and $(15.7 \mathrm{mg} / \mathrm{kg})$ in site 15 during September as a maximum value. Statistically, there were significant differences at $(\mathrm{P}<0.05)$ among studied samples (Figure 3). The results of the current investigation showed that, soil sample total Co concentration were within normal levels of soil concentration of cobalt. Occurrence for cobalt might have been of anthropogenic sources include fossil fuel burning, processing of oil refining, dumping sewage sludge, wastewater main channel of Erbil, and agricultural use of phosphate fertilizers that cause increasing soil $\mathrm{Co}$ concentration indirectly through increasing Co concentration in irrigation water (45). Cobalt concentration was drastically reduced during rainy season, this could be related to dilution effect with rain water and the highest concentration was noticed during dry season, with small fluctuation of its concentration in some sampling sites, as noticed by (32). The results showed that, greenhouse practices increased the soil total $\mathrm{Zn}$ concentrations from (121.4 \pm 5.9 to $134.7 \pm 5.4 \mathrm{mg} / \mathrm{kg})$. According to recorded results, the concentration of zinc in soil samples recorded $(82 \mathrm{mg} / \mathrm{kg})$ as the lowest concentration at site 14 during March and (186 $\mathrm{mg} / \mathrm{kg}$ ) as the highest value at site 13 during September (Figure 4). Statistically there was significant differences at $(\mathrm{P}<0.05)$ among studied samples. The observed data of the current study, showed that greenhouse practices increased the soil total $\mathrm{Zn}$ concentrations. Increasing $\mathrm{Zn}$ concentration during second sampling dates within greenhouse soil was noticed to be higher, which were closely related to the pollutants in irrigation water especially during using wastewater directly for irrigation, agricultural soil fertilizers, and used pesticides. These results are in accordance with recent studies $(44,22)$. Although an enrichment of soils with $\mathrm{Zn}$ has been reported when these materials were used during long-term repeated additions, after the abandonment of agricultural applications and remaining trace metals in the soil (30). The highest value of total $\mathrm{Pb}$ in soil was measured $(48 \mathrm{mg} / \mathrm{kg})$ in site 10 during September, while the lowest value $(17 \mathrm{mg} / \mathrm{kg})$ in sites 2, 12, and 14 during March and site 14 during September, with statistically, significant differences at $(\mathrm{P}<0.05)$ among studied samples (Figure 5). Mean concentration of soil $\mathrm{Pb}$ soil samples was $(23.13 \pm 1.76$ and $24.13 \pm 1.99 \mathrm{~g} / \mathrm{kg})$ during studied period. All results were within acceptable limits of WHO, except in site 10, which wastewater directly was used for irrigation. Increasing greenhouse total soil $\mathrm{Pb}$ concentration during second sampling dates, might be because of leaching lead from oil refinery projects and percolation to groundwater that cause increasing greenhouse soil total $\mathrm{Pb}$ concentration through irrigation. These results were in accordance to previous studies $(19,44)$. Previous study concluded that, lead concentration was increased after fertilization, and increased two times after harvesting, as well as, atmospheric deposition, manure, and sludge application (31). Soil samples revealed that the concentration of total $\mathrm{Cr}$ was ranged between (281ppm) in site 14 during March as a minimum value to maximum value $(545 \mathrm{ppm})$ in site 5 during September, with mean of $(403.2 \pm 16.47$ and $417.4 \pm 15.47 \mathrm{ppm})$. Statistically, there were significant differences at $(\mathrm{P}<0.01)$ among studied samples (Figure 6). The concentration of $\mathrm{Cr}$ in the greenhouse soils exceed the concentrations in the background soils, which, indicated that greenhouse cultivation and application of pesticides and livestock manure had a significant effect on the concentrations of $\mathrm{Cr}$ in irrigated soil (5). Recent study reported that parent rocks mainly determine $\mathrm{Cr}$ concentrations in greenhouse soil fields (22). The total Ni concentration in studied soil was ranged between $(181.1 \pm 3.14$ to $187 \pm 3.39$ $\mathrm{g} / \mathrm{kg})$, the highest value was $(214 \mathrm{~g} / \mathrm{kg})$ recorded during September at site 7 , and the 
lowest value recorded $(155 \mathrm{~g} / \mathrm{kg})$ in site 9 during March (Figure 7). Statistically, there were significant differences were found at $(\mathrm{P}<0.05)$ among studied samples during studied period. Total Ni concentration showed slight variation in studied sampling fields, which might be related to atmospheric deposition, due to occurrence of industrial and oil refinery projects, application of fertilizers and pesticides, industrial effluents of steel factory, and $\mathrm{Ni}$ concentration of irrigated water especially in some places wastewater was directly used for irrigation, as concluded previously $(8,28,30)$.

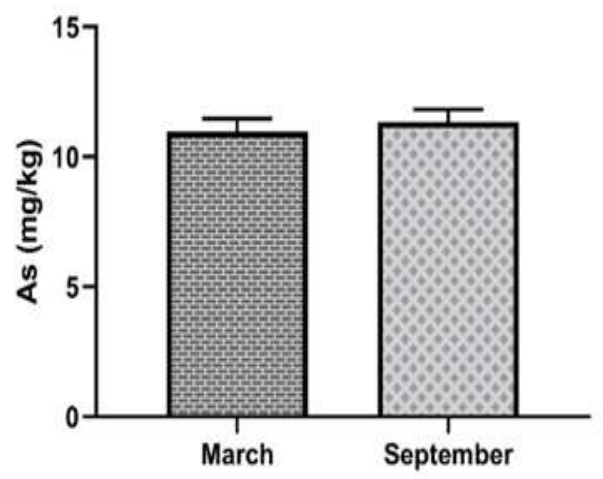

Figure 1. Soil total As $(\mathrm{mg} / \mathrm{kg})$ in the studied sites

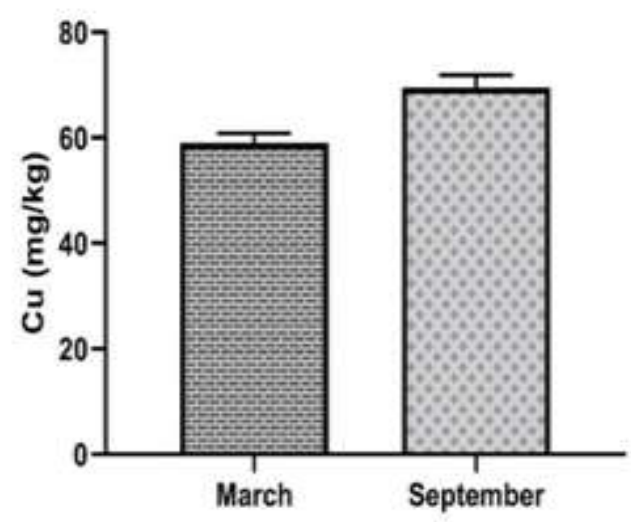

Figure 2. Soil $\mathrm{Cu}(\mathrm{mg} / \mathrm{kg})$ in the studied sites

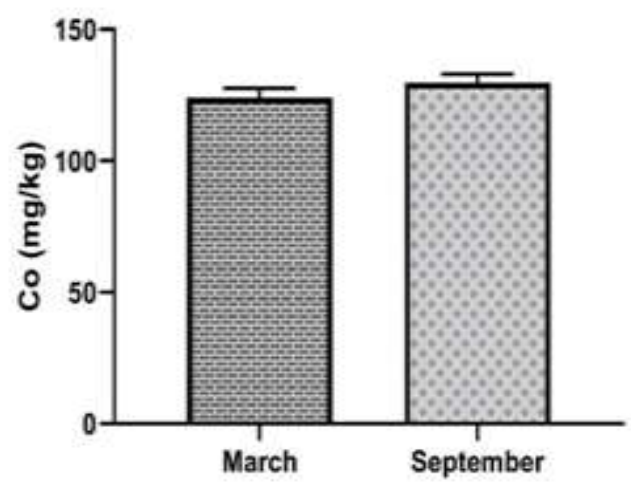

Figure 3. Soil Co $(\mathrm{mg} / \mathrm{kg})$ in the studied sites

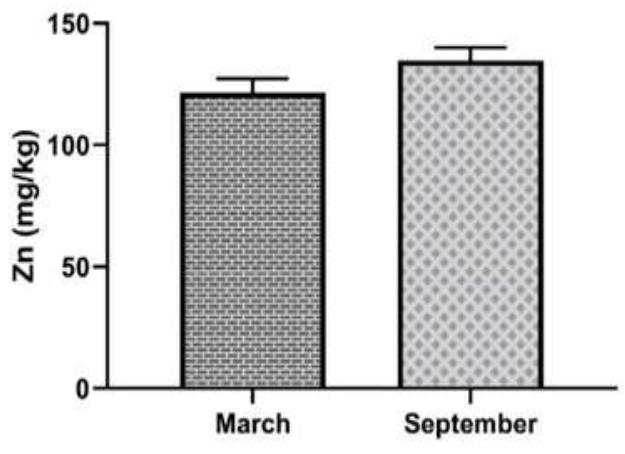

Figure 4. Soil total $\mathrm{Zn}(\mathrm{mg} / \mathrm{kg})$ in the studied site

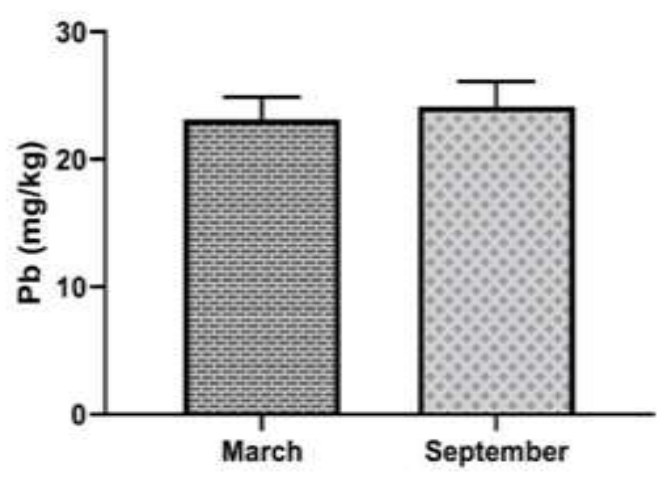

Figure 5. Soil total $\mathrm{Pb}\left(\mathrm{mg} \mathrm{kg}^{-1}\right)$ in the studied sites

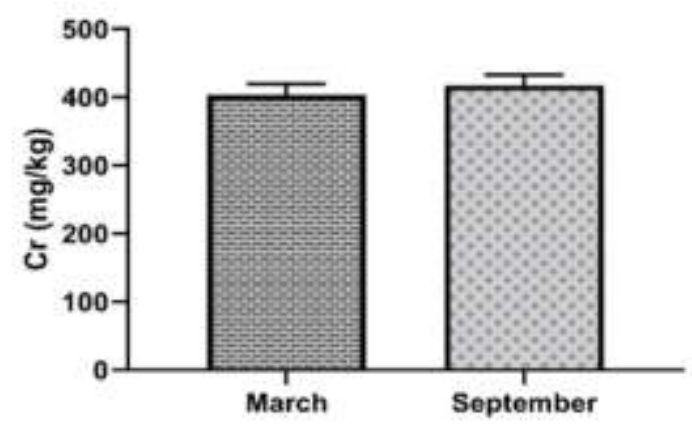

Figure 6. Soil $\mathrm{Cr}(\mathrm{mg} / \mathrm{kg})$ in the studied sites Figure 8. Soil total Mn $\left(\mathrm{g}^{\mathrm{kg}}{ }^{-1}\right)$ in the studied site

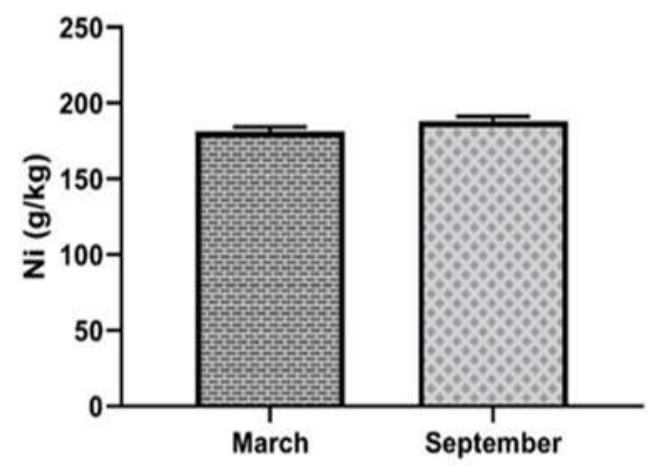

Figure 7. Soil total $\mathrm{Ni}(\mathrm{g} / \mathrm{kg})$ in the studied sites 


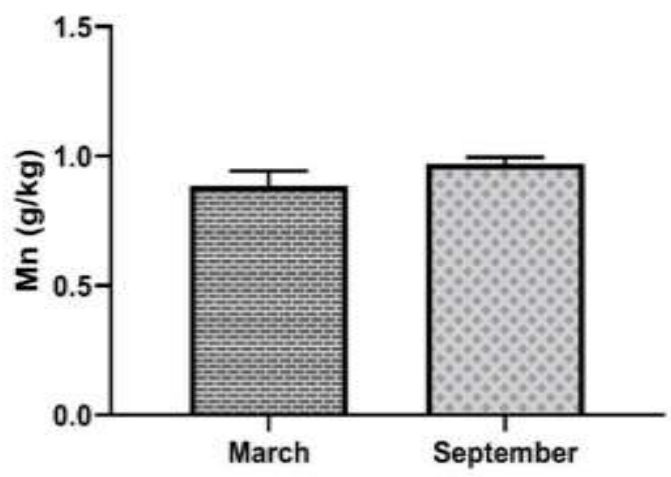

Figure 8. Soil total Mn $\left({\left.\mathrm{g} . \mathrm{kg}^{-1}\right)}^{-1}\right.$ in the studied site

Total manganese is relatively abundant in studied soil samples $(0.886 \pm 0.057$ and $0.970 \pm 0.025 \mathrm{~g} / \mathrm{kg}$ ), the lower concentration was ranged from $(0.740 \mathrm{~g} / \mathrm{kg})$ in site 14 during March to highest concentration $(1.18 \mathrm{~g} / \mathrm{kg})$ in site 5 during September. Statistically, there were non-significantly increasing $\mathrm{Mn}$ among studied samples (Figure 8). The Mn content of the greenhouse soil were increased in most studied fields, which related to application of fertilizers and pesticides in closed greenhouse with high humidity content (6). Manganese is a part of an important antioxidant structure that protects plant cells by deactivating free radicals (29). Previous study concluded that irregular use of phosphate fertilizers in the poor soils of micronutrients, leads to decreasing manganese concentration and effects crop yields in greenhouses, due to precipitation them in the form of $\mathrm{MnPO}_{4}$ or $\mathrm{Mn}_{3}\left(\mathrm{PO}_{4}\right)_{2}(1)$.

\section{Soil contamination indices}

Results in the Table (2), show contamination factor $(\mathrm{CF})$ results of heavy metals in studied greenhouse that the $\mathrm{CF}$ for all metals were in the descending order of $\mathrm{Pb}>\mathrm{Zn}>\mathrm{As}>\mathrm{Cu}>$ $\mathrm{Mn}>\mathrm{Co}>\mathrm{Ni}>\mathrm{Cr}$, with the mean $\mathrm{CF}$ values 0.337, 0.512, 0.929, 1.019, 1.031, 3.171, 4.097 and 6.411 respectively. All studied sites showed lower contamination within $\mathrm{Zn}$ and $\mathrm{Pb}$ (Figure 9). The value of CF of mean studied sites for $\mathrm{Pb}, \mathrm{Zn}$ and As metals showed low degree of contamination $(\mathrm{CF}<1)$, and $\mathrm{Cu}$ and Mn showed moderate contamination degree (1 $\leq \mathrm{CF} \leq 3$ ), whereas, $\mathrm{Co}$ and $\mathrm{Ni}$ recorded as highest contamination factor $(3 \leq \mathrm{CF} \leq 6)$, while $\mathrm{Cr}$ values showed very high contamination factor $(\mathrm{CF}>6)$. The contamination factor of studied greenhouse soil heavy metals during studied period can be used to reflect the degree of human-caused disturbance on the soil pollution through agriculture activities, however, the soil from the various sites were not contaminated in equal state. As well as, soil samples from site 5 showed highest pollution rate, and lower polluted samples were from site 6 . Very high greenhouse soil contamination was recorded with $\mathrm{Cr}$ in sites 5, 12, 13, 16, 3, 10, 7, 15, 2, 8, 4 and 9 in descending order. Highest contaminated were obtained with $\mathrm{Cr}$ in sites $11,1,14$ and 6 , while with $\mathrm{Ni}$ at sites 1 to 16 and with Co at sites 15, 16, 3, 12, 5, 1, 11, 4, 9, 8 and 10 . However moderately contamination were recorded with Co on sites 14, 2, 7 and 6, with $\mathrm{Mn}$ in sites 5, 1, 16, 3, 9, 8, 4, 15, 7 and 2 , with $\mathrm{Cu}$ at sites $10,2,5,13,16,11,4,1$ and 9, and with As in sites 16, 1, 15, 4, 2, 5. Lower contamination were observed with $\mathrm{Mn}$ in sites $12,13,11,6,14$ and 10 , with $\mathrm{Cu}$ at sites 3,12 , 8, 14, 15, 6 and 7, with As in sites 11, 3, 13, 6, 8, 14, 7, 12, 9 and 10. All sites showed lower contamination within $\mathrm{Zn}$ and $\mathrm{Pb}$. Obtained results were in accordance to $(3,40)$. The assessment of PLI values of metals in soil samples were showed in (Figure 10 and Table 2 ), which were ranged from the minimum value 1.166 in site 14 to maximum value 1.568 in site 16 during studied period. It is supporting that the soil of the studied greenhouse was contaminated (The PLI value $<1$ indicates no pollution, whereas PLI value $>1$ is polluted). However, the highest PLI values in site 16 indicated that $\mathrm{Cr}, \mathrm{Ni}$ and $\mathrm{Co}$ were the major contributors to the soil pollution. Highest PLI values in sites $16,4,13$, 11 and 3 were calculated in sampling sites, was an indicator of industrial and oil refinery project activity inputs on studied sites, and higher polluted fields were near those projects, which might been because of atmospheric deposition of air pollutant discharges, all other sampled greenhouse fields show that, the soils were moderately polluted with heavy metals. Same results were observed by $(2,9,12)$. 


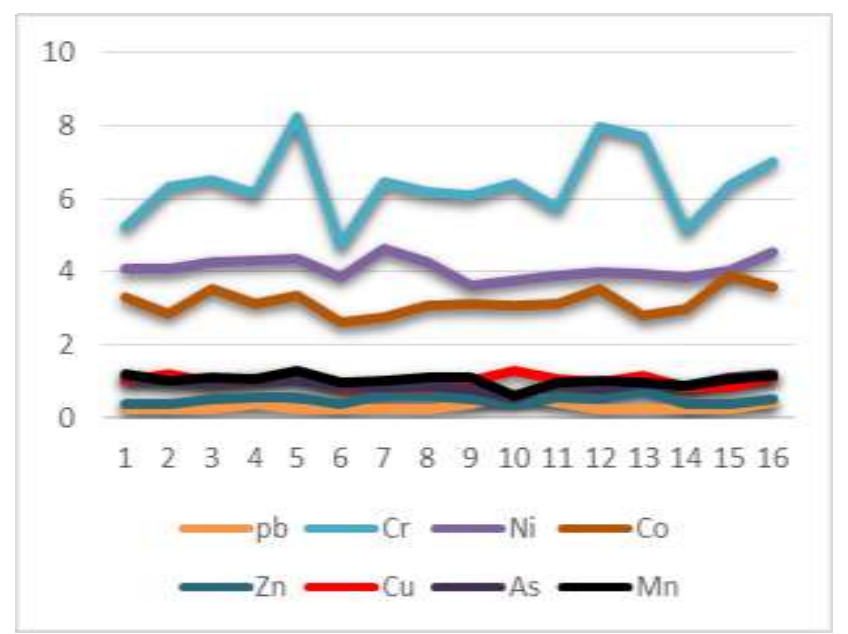

Figure 9. Heavy metals contamination factor

Results in Table 3 shows, pesticide residues accumulation in studied sites according to the $\mathrm{CF}$ were in the descending order of Spirodiclofen $>$ Pyridaben $>$ Thiamethoxam $>$

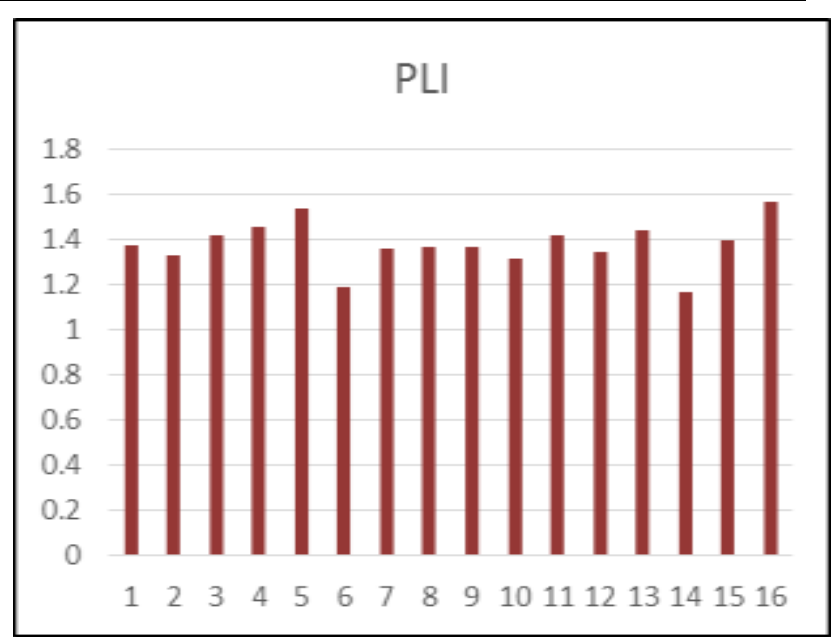

Figure 10. show soil heavy metals PLI

Abamectin. The mean $\mathrm{CF}$ values of Spirodiclofen, Pyridaben, Thiamethoxam and Abamectin were 4.185, 4.083, 3.409 and 0.201 respectively (Figure 11).

Table 2. Soil heavy metal Contamination Factor and PLI

\begin{tabular}{|c|c|c|c|c|c|c|c|c|c|}
\hline \multirow{2}{*}{ Sites } & \multicolumn{8}{|c|}{ Contamination Factors $(\mathbf{C F})$} & \multirow{2}{*}{ PLI } \\
\hline & Mn & As & $\mathbf{C u}$ & $\mathbf{Z n}$ & Co & $\mathbf{N i}$ & $\mathbf{C r}$ & pb & \\
\hline Site 1 & 1.205 & 1.1 & 1.024 & 0.438 & 3.3 & 4.078 & 5.258 & 0.3 & 1.373 \\
\hline Site 2 & 1.018 & 1.013 & 1.190 & 0.452 & 2.863 & 4.067 & 6.336 & 0.243 & 1.332 \\
\hline Site 3 & 1.117 & 0.946 & 0.976 & 0.516 & 3.55 & 4.278 & 6.539 & 0.307 & 1.417 \\
\hline Site 4 & 1.072 & 1.079 & 1.048 & 0.532 & 3.137 & 4.311 & 6.141 & 0.371 & 1.453 \\
\hline Site 5 & 1.283 & 1.012 & 1.15 & 0.532 & 3.337 & 4.344 & 8.265 & 0.321 & 1.535 \\
\hline Site 6 & 0.957 & 0.875 & 0.869 & 0.414 & 2.625 & 3.877 & 4.742 & 0.271 & 1.186 \\
\hline Site 7 & 1.021 & 0.85 & 0.857 & 0.64 & 2.738 & 4.633 & 6.461 & 0.3 & 1.36 \\
\hline Site 8 & 1.116 & 0.871 & 0.928 & 0.598 & 3.075 & 4.277 & 6.195 & 0.271 & 1.363 \\
\hline Site 9 & 1.117 & 0.792 & 1.008 & 0.48 & 3.112 & 3.622 & 6.101 & 0.407 & 1.364 \\
\hline Site 10 & 0.608 & 0.5 & 1.278 & 0.472 & 3.075 & 3.778 & 6.453 & 0.664 & 1.318 \\
\hline Site 11 & 0.961 & 0.958 & 1.063 & 0.55 & 3.138 & 3.911 & 5.765 & 0.428 & 1.418 \\
\hline Site 12 & 0.988 & 0.792 & 0.944 & 0.514 & 3.525 & 3.989 & 7.976 & 0.25 & 1.344 \\
\hline Site 13 & 0.978 & 0.933 & 1.119 & 0.73 & 2.787 & 3.967 & 7.726 & 0.286 & 1.437 \\
\hline Site 14 & 0.849 & 0.867 & 0.881 & 0.368 & 2.987 & 3.833 & 5.172 & 0.243 & 1.166 \\
\hline Site 15 & 1.064 & 1.087 & 0.873 & 0.47 & 3.9 & 4.044 & 6.398 & 0.307 & 1.399 \\
\hline Site 16 & 1.144 & 1.196 & 1.103 & 0.49 & 3.587 & 4.555 & 7.047 & 0.429 & 1.568 \\
\hline Mean & 1.031 & 0.929 & 1.020 & 0.512 & 3.171 & 4.098 & 6.411 & 0.337 & \\
\hline
\end{tabular}

The contamination factor of studied greenhouse soil pesticide residues might be reflecting the degree of human-caused disturbance on the soil pollution during pesticide application. The soil from the various sites were not contaminated equally, in a manner that, there were non-contamination factor recorded in most sites with Abamectin, and in some sites with spirodiclofen. Higher contaminated sites were observed within thiamethoxam and Pyridaben. Lower contamination factor was recorded with Abamectin in sites 16 and 1, with Thiamethoxam in sites 8, 6, 4, 2, 3 and 9, with spirodiclofen in sites 8,10 and 9, and with Pyridaben in sites 2 and 9. Moderately contamination factor was illustrated in sites 11 and 7 with Abamectin, sites 13, 12, 1, 11 and 7 with Thiamethoxam, sites 13, 12, 10, 7, 11, 5 and 4 in descending order. There was highly contamination factor within site 16 with thiamethoxam, spirodiclofen and pyridabin. 
While very high contamination factor was recorded within thiamethoxam in sites 14 and 15 , with spirodiclofen in sites $12,1,11,7,14$ and 15 and with Pyridaben in sites 14, 15 and 1. Based on background values and recorded contamination factors of studied pesticides there were pollution impacts of pesticides on studied greenhouses during investigated period, this could be due to improper application of pesticides and lack of willingness to apply the necessary dosage of pesticides in greenhouses by sprayers. The assessed pollution load index (PLI) values of accumulated pesticides in greenhouses soil samples were showed in (Figure 12 and Table 4), which were ranged from maximum 7.751 in site 14 to minimum 0.303 in site 2 during studied period, which supporting that the soil of the studied cucumber greenhouse fields was contaminated in 9 sites and non-contaminated in other 7 sites during studied period. However, the higher PLI values in site 14 and 15 indicated that thiamethoxam, pyridabin and spirodiclofen were the major contributors of pesticide accumulation. Higher PLI values in sites $14,15,1,11,7$ and 12 were recorded, and the rate of PLI were lower in sites 16, 13 and 5. Recorded PLI value was an indicator of improper application of studied pesticides within greenhouses. However, there were nonpollution effects of used pesticides in sites 10 , $3,4,6,9,8$ and 2 , which might be due to photodegradation property, soil microorganism activity and quantity of used doses of detected pesticide. The study was revealed that the pesticide residues of pyridabine, thiamethoxam, abamectin and spirodiclofen residues were detected in greenhouse soil samples. The value of soil heavy metal contamination factor (CF) revealed that studied greenhouse soil ranged from low contamination to very high contamination, while for pesticides from non to high contaminated. On the bases of the PLI, the studied soil samples contaminated in most sites during the studied period.

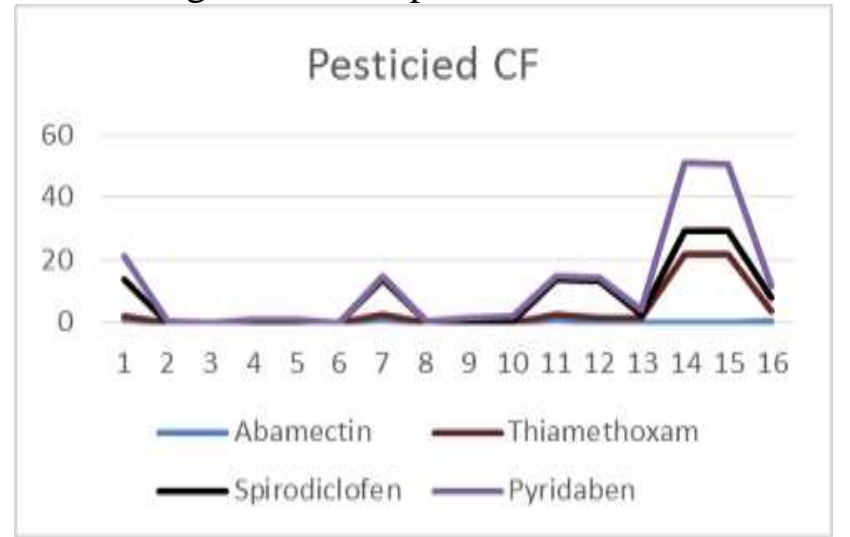

Figure 11. Pesticide contamination factor

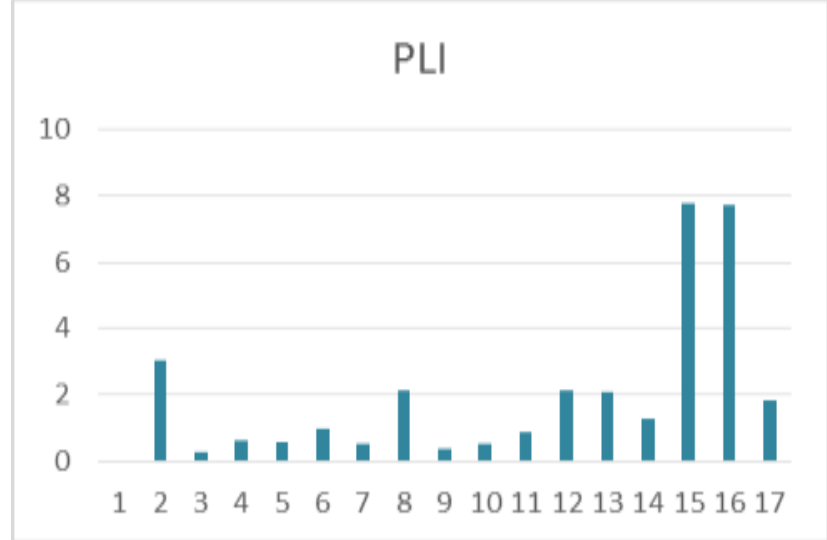

Figure 12. Soil Pesticide Residues PLI

Table 3. Pesticide Contamination Factor and PLI

\begin{tabular}{|c|c|c|c|c|c|}
\hline \multirow{2}{*}{ ites } & \multicolumn{4}{|c|}{ Contamination Factors (CF) } & \multirow[t]{2}{*}{ PLI } \\
\hline & Abamectin & Thiamethoxam & Spirodiclofen & Pyridaben & \\
\hline Site 1 & 0.694 & 1.326 & 11.513 & 7.95 & 3.03 \\
\hline Site 2 & 0 & 0.135 & 0 & 0.066 & 0.307 \\
\hline Site 3 & $\mathbf{0}$ & 0.139 & $\mathbf{0}$ & 0 & 0.611 \\
\hline Site 4 & $\mathbf{0}$ & 0.115 & $\mathbf{0}$ & 1.010 & 0.584 \\
\hline Site 5 & $\mathbf{0}$ & $\mathbf{0}$ & $\mathbf{0}$ & 1.039 & 1.010 \\
\hline Site 6 & $\mathbf{0}$ & 0.083 & $\mathbf{0}$ & $\mathbf{0}$ & 0.537 \\
\hline Site 7 & 1.136 & 1.309 & 11.268 & 1.242 & 2.136 \\
\hline Site 8 & $\mathbf{0}$ & 0.063 & 0.34 & $\mathbf{0}$ & 0.383 \\
\hline Site 9 & 0 & 0.173 & 0.498 & 0.855 & 0.521 \\
\hline Site 10 & 0 & 0 & 0.494 & 1.272 & 0.890 \\
\hline Site 11 & 1.183 & 1.314 & 11.177 & 1.228 & 2.149 \\
\hline Site 12 & 0 & 1.330 & 11.625 & 1.284 & 2.111 \\
\hline Site 13 & 0 & 1.734 & 0.837 & 1.783 & 1.268 \\
\hline Site 14 & 0 & 21.71 & 7.586 & 21.92 & 7.751 \\
\hline Site 15 & 0 & 21.706 & 7.443 & 21.61 & 7.687 \\
\hline Site 16 & 0.201 & 3.409 & 4.185 & 4.084 & 1.85 \\
\hline Mean & 0.201 & 3.409 & 4.185 & 4.083 & \\
\hline
\end{tabular}




\section{REFERENCES}

1. Abdou, A.S., F.H. Al-Darwish, M.E. Saleh, K.A. El-Tarabily, M.S. Azirun and M.M. Rahman .2011. Effects of elemental sulfur, phosphorus, micronutrients and paracoccus versutus on nutrient availability of calcareous soils. Australian Journal of Crop Science, 5(5): 554-561

2. Adimalla, N., H. Qian, and H. Wang. 2019. Assessment of heavy metal (HM) contamination in agricultural soil lands in northern Telangana, India: an approach of spatial distribution and multivariate statistical analysis. Environmental Monitoring and Assessment, 191(4), p.246

3. Antisari, L.V., S. Carbone, C. Ferronato, A. Simoni and G. Vianello. 2011. Characterization of heavy metals atmospheric deposition for assessment of urban environmental quality in the Bologna city (Italy). EQA-International Journal of Environmental Quality, 7(7):49-63

4. Arora, S., S. Arora, D. Sahni, M. Sehgal, D.S. Srivastava and A. Singh. 2019. Pesticides use and its effect on soil bacterial and fungal populations, microbial b activity. Current Science, 116(4):643-649

5. Bai, L.Y., X. B. Zeng, S. M. Su, R. Duan, Y. N. Wang and X. Gao. 2015. Heavy metal accumulation and source analysis in greenhouse soils of Wuwei District, Gansu Province, China. Environmental Science and Pollution Research, 22(7):5359-5369

6. BaşayĬğİt, L., P. Alaboz, O. Özçer and A. A. Issildar. 2015. The movement of copper, zinc and manganese in the soil of cut flower production greenhouses and fields. Scientific Papers-Series A, Agronomy, 58:26-31

7. European Food Safety Authority (EFSA), M. Arena, D. Auteri, S. Barmaz, A. Brancato, D. Brocca, L. Bura, L. Carrasco Cabrera, A. Chiusolo, D. Court Marques and F. Crivellente. 2018. Peer review of the pesticide risk assessment of the active substance spinosad. EFSA Journal, 16(5): e05252

8. Fosu-Mensah, B.Y., E. Addae, D. YirenyaTawiah and F. Nyame. 2017. Heavy metals concentration and distribution in soils and vegetation at Korle Lagoon area in Accra, Ghana. Cogent Environmental

Science, 3(1):1405887
9. Genç, T.O. and F. Yılmaz. 2016. Metal pollution assessment in water and sediment of Sarıçay stream in Muğla-Turkey. Journal of Chemical and Pharmaceutical Research, 8(8):786-794

10. Gil, C., R. Boluda, J. A. Rodríguez Martín, M. Guzmán, F. del Moral and J. Ramos-Miras. 2018. Assessing soil contamination and temporal trends of heavy metal contents in greenhouses on semiarid land. Land degradation and development, 29(10):33443354

11. Heikens, A. 2006. Arsenic contamination of irrigation water, soil and crops in Bangladesh: Risk implications for sustainable agriculture and food safety in Asia. RAP Publication (FAO).

12. HO, N. and A. J. Ememu. 2018. Contamination indices and heavy metal concentrations in Soils in okpoko and environs, South eastern Nigeria. J Environ Sci, 2(2):77-95

13. Jiandani, M.A. 2015. Soil adsorption of pesticides used on vegetables in southern Sindh (Doctoral dissertation, University of Sindh Jamshoro, Sindh).

14. Jodeh, S., S. Al Masri, M. Haddad, O. Hamed, D. Jodeh, R. Salghi, S. Radi, J. Amarah, F. El-Hajjaji and I. Warad, 2016. Evaluation of potential Residue of Imidacloprid and Abamectin in Tomato, Cucumber and Pepper Plants after Sprayingusing High Performance Liquid Chromatography (HPLC). J. Mater. Environ. Sci. 7 (3): 1037-1047

15. Kanungo, D. and R. Pfeil, 2015. First draft prepared by D. Kanungo1 and Rudolf Pfeil2 Food Safety and Standards Authority of India, Faridabad, India. Federal Institute for Risk Assessment (BfR), Berlin, Germany

16. Khaghani, R., M. A. Mirhosseini and Y. Fathipour. 2018. Household activities can reduce imidacloprid and abamectin residues in greenhouse crops. Journal of Agricultural Science and Technology, 20(4): 775-786 17. Khalid, S., M. Shahid, N. K. Niazi, B. Murtaza, I. Bibi and C. Dumat. 2017. A comparison of technologies for remediation of heavy metal contaminated soils. Journal of Geochemical Exploration, 182: 247-268

18. Khan, M.A.R., M. H. Ara and P. K. Dhar, 2019. Assessment of heavy metals 
concentrations in the soil of Mongla industrial area, Bangladesh. Environmental Health Engineering and Management Journal

19. Khudhur, N.S., S. M. Khudhur and I. N. Ahmad. 2016. an assessment of heavy metal soil contamination in a steel factory and the surrounding area in Erbil Cit. Jordan Journal of Earth and Environmental Sciences, 9 (1) :111

20. Kroon, F., C. Streten and S. Harries. 2017. A protocol for identifying suitable biomarkers to assess fish health: A systematic review. PloS one, 12(4): e0174762

21. Leili, M., A. Pirmoghani, M. T. Samadi, R. Shokoohi, G. Roshanaei and A. Poormohammadi. 2016. Determination of pesticides residues in cucumbers grown in greenhouse and the effect of some procedures on their residues. Iranian Journal of Public Health, 45(11): 1481

22. Liao, Z., Y. Chen, J. Ma, M. Islam, L. Weng and Y. Li. 2019. Cd, Cu, and $\mathrm{Zn}$ Accumulations caused by long-term fertilization in greenhouse soils and their potential risk assessment. International Journal of Environmental Research and Public Health, 16(15): 2805

23. Liu, C., D. Lu, Y. Wang, J. Huang, K. Wan and F. Wang. 2014. Residue and risk assessment of pyridaben in cabbage. Food chemistry, 149: 233-236

24. Lozowicka, B., E. Abzeitova, A. Sagitov, P. Kaczynski, K. Toleubayev and A. Li. 2015. Studies of pesticide residues in tomatoes and cucumbers from Kazakhstan and the associated health risks. Environmental monitoring and assessment, 187(10): 609

25. Lv, P., Z. Wei, Z. Yu, J. Zhang and L. Wang. 2019. Heavy metal contamination in soils of greenhouse vegetable production systems in a cold region of China. International Journal of Agricultural and Biological Engineering, 12(2): 98-102 26. Malhat, F.M., A. El-Mesallamy, M. Assy, W. Madian, N. M. Loutfy and M. T. Ahmed. 2015. Health hazard assessment of pyridaben residues in Egyptian strawberries. Human and Ecological Risk Assessment: An International Journal, 21(1): 241-249

27. Manual, R. N. C. U. 2014. Energy Dispersive X-RAY Fluorescence Spectrometer
28. Mohammadpour, G., A. Karbassi and A. Baghvand. 2016. Pollution intensity of nickel in agricultural soil of Hamedan region. Caspian Journal of Environmental Sciences, 14(1): 15-24

29. Mousavi, S.R., M. Shahsavari and M. Rezaei. 2011. A general overview on manganese (Mn) importance for crops production. Australian Journal of Basic and Applied Sciences, 5(9) :1799-1803

30. Navarro-Pedreno, J., M. Almendro-Candel, I. Gómez Lucas, M. Jordán Vidal, J. Bech Borras and A. Zorpas. 2018. trace metal content and availability of essential metals in agricultural soils of Alicante (Spain). Sustainability, 10(12): 4534

31. Nicholson, F.A., S. R. Smith, B. J. Alloway, C. Carlton-Smith and B. J. Chambers. 2003. An inventory of heavy metals inputs to agricultural soils in England and Wales. Science of the total environment, 311(1-3): 205-219

32. Oladeji, S.O. and M. D. Saeed. 2015. Assessment of cobalt levels in wastewater, soil and vegetable samples grown along Kubanni stream channels in Zaria, Kaduna State, Nigeria. African Journal of Environmental Science and Technology, 9(10): 765-772

33. Pigna, M., A. G. Caporale, L. Cavalca, A. Sommella and A. Violante. 2015. Arsenic in the soil environment: mobility and phytoavailability. Environmental Engineering Science, 32(7): 551-563

34. Rahman, S.H., D. Khanam, T. M. Adyel, M. S. Islam, M. A. Ahsan, and M.A. Akbor. 2012. Assessment of heavy metal contamination of agricultural soil around Dhaka Export Processing Zone (DEPZ), Bangladesh: implication of seasonal variation and indices. Applied sciences, 2(3): 584-601 35. Rand, G.M. and J. R. Clark. 2000. Hazard/risk assessment of pyridaben: I. Aquatic toxicity and environmental chemistry. Ecotoxicology, 9(3): 157-168

36. Sverdrup, L.E., C. Bjørge, O. M. Eklo, T. Källqvist, I. Klingen, M. Låg, E. Rivedal, E. Ropstad, S. Øvrebø and M. Grung. 2011. Risk assessment of the pesticide Envidor with the active substance spirodiclofen. Opinion of the Panel on plant protection products Norwegian Scientific Committee for Food Safety. VKM Report 
37. Szpyrka, E., M. Slowik-Borowiec, A. Matyaszek, M. Podbielska and J. Rupar. 2016. Pesticide residues in raw agricultural products from the south-eastern region of Poland and the acute risk assessment. Roczniki Państwowego Zakładu Higieny. 67(3).

38. Tian, K., W. Hu, Z. Xing, B. Huang, M. Jia and M. Wan. 2016. Determination and evaluation of heavy metals in soils under two different greenhouse vegetable production systems in eastern China. Chemosphere, 165: 555-563

39. USAID. 2008. Soil testing. Perennial Crop Support Series. Jalalabad, Afghanistan. Publication No. 2008-001-AFG. February 8

40. Van der Oost, R., J. Beyer and N. P. Vermeulen.2003. Fish bioaccumulation and biomarkers in environmental risk assessment: a review. Environmental Toxicology and Pharmacology, 13(2): 57-149

41. Wang, W.H., X. G. Luo, Z. Wang, Y. Zeng, F. Q. Wu and Z. X. Li. 2018. Heavy metal and metalloid contamination assessments of soil around an abandoned uranium tailings pond and the contaminations' spatial distribution and variability. International journal of environmental research and public health, 15(11): 2401

42. Wood, T.J. and D. Goulson. 2017. The environmental risks of neonicotinoid pesticides: a review of the evidence post 2013. Environmental Science and Pollution Research, 24(21): 17285-17325

43. World Health Organization. 2019. Pesticide residues in food-2018: Toxicological Evaluations: Joint Meeting of the FAO Panel of Experts on Pesticide Residues in Food and the Environment and the WHO Core Assessment Group on Pesticide Residues, Berlin, Germany, 18-27 September 2018

44. Yang, J., F. Lv, J. Zhou, Y. Song and F. Li. 2017. Health risk assessment of vegetables grown on the contaminated soils in daye city of Hubei Province, China. Sustainability, 9(11): 2141

45. Yasmeen K, M. Versiani, R. Arain, Q. Haque, N. Khan, S. Ali and A. Langha. 2010. Enhanced metal levels in vegetables and farm soil irrigated with industrial wastewater. J. Appl. Sci. Environ. Manage. 14: 95-99. 